\title{
VIHANG A NAIK-A STUDY OF HIS MIND AND ART
}

\section{MARY SURYA KALA}

Research Scholar, Prist University, Vallam, Thanjavur, Tamil Nadu, India

\begin{abstract}
The book is the portrayal of Vihang A Naik's ingenious deep inherent poetic verses, which gives the unusual pattern of thinking by the modern man, related to the city life. Poetry is the form of literary work in which the expression of feelings and ideas is given the intensity of the use of distinctive style and rhythm, poems collectively or as a genre of literature. In other words, it is the spontaneous overflow of thoughts. Some poems that run naturally and unintentionally will never be forgotten by the readers. The lines of such poems will blend with the blood of the readers. Particularly, poetry concubines can never forget such pervasive and poignant lines. The poetry lovers keep them reserved in their hearts forever. These kind of poetic verses will never be separated from the readers' mind. Vihang $A$ Naik is one such writer, who captures the minds of the readers by his simple verses with effective simile and metaphor to suit the theme of the poem. His writings are too modest that the readers can register the verses reluctantly.

KEYWORDS: Unrequited, Mesmerizing, Repulsive, Declining Morality, Thoughtful, Imaginative, Prudish, Gyrates, Malicious \& Resourceful
\end{abstract}

Received: Sep 21, 2018; Accepted: Oct 11, 2018; Published: Nov 29, 2018; Paper Id.: IJELDEC201811

\section{INTRODUCTION}

The art of poetry gets much less explanation than it deserves. The artist is too busy pioneering, the inflexible critic too busy fighting his own battles in the modern world. Nor does any explanation come from the critics. They have a fear of tasting anything which they cannot recognize at a glance, they refuse to understand anything which is disturbingly new. English Poetry has undergone various phases due to the age of transition and since its beginning many poets have enhanced it through their poetry. Several poets have emerged on the literary platform of poetry, but a few of them have won laurels due to their intellectual excellence, sophisticated style, attractive usage of words and the burning issues of the contemporary society. Vihang A Naik is one of them who has brought out his far-reaching verses in simple and elegant style. His poems are aesthetic in nature, crisp and brilliant in their theme.

\section{About the Poet}

The book was first published in the year 2018 and it was edited by Dr. Sanjay Prasad Pandey. The book was the compilation of interviews, articles and papers by research scholars and critics. Vihang A Naik, a far and wide commended Indian poet, critic and editor in English. He was born on $2^{\text {nd }}$ of September 1969in Surat of South Gujarat. Vihang A Naik is a famous bilingual poet who was born in Surat, Gujarat in 1969. He did his schooling from Navrachna School in Vadodara, Gujarat. He has completed his graduation and post-graduation in English from Maharaja Sayajirao University of Baroda. He has read English and philosophy in his graduation that is why he has written very deeply on philosophy and about the declining morality, especially in India, a land of tradition and custom. He presently works as an Associate Professor in the Department of English at Shree Ambaji Arts 
College, Ambaji. He has achieved a great reputation on the basis of his poetry and translation works. He is one of the pioneer contemporary poets and his poetry has varied themes. He has published four books of poetry. His first poetry collection City Times and Other Poems (1993) was published by Writers Workshop, Kolkata. Jeevangeet (2001) is his collection of Gujarati poems and it was published in the year 2001. His next poetry collection Making A Poem was published in 2004 and his fourth poetry collection Poetry Manifesto: New \& Selected Poems was published in April 2010 from Indialog Publications, New Delhi.

Vihang A Naik has an excellent way of writing poetry and his choice of words is matchless. His teaching profession had wrought his personality and he started to compose poems. It is not the inheritance from his parents, nor influenced by any one. Teaching and writing passed into his blood naturally. He is a poet of human community as his poems contracts with human nature. His poems make the reader to be repulsive, thoughtful, imaginative and resourceful. His poetry is a liquid to the avid readers who want to learn different lessons of the modern man's life. His poetry works as an escape in the torrid experiences of life. The love depicted in his poetry is not a puppy love; his love is mature, pure and devoid of egocentricity and self-centeredness. Readers find a sparkling experience at the time of perusal of his poetry. His poetry also serves as a critique of many social issues of Indian society. He is India's well known poet of the modern age, who is cordially devoted to the Indian literature.

\section{MESMERIZING THEMES}

His lucid configuration of verses suits his simple themes. He has taken themes from all fetters of life. He believes that poetry is the countenance of human emotions and the ugly inner self of modern man. His themes gyrates from love to lust, obscene to prudish, malicious to compassionate, dreams to realism etc.

In Mirrored Men he takes the everyday endurance technique of a spider, crab and chameleon to express the vicious inner self of a modern man.It has been evaluated in a metaphorical way that man keeps on changing with the passage of time with his nature like a spider and a chameleon. The reader is fascinated by the mirror look of a man and nobody is aware about the nature of man in the modern world. The poem is related to the existential dilemma of modern man. He is intensely aware of the alienation and isolation of modern man, whois coiled in the net of deceit and exploitation. The man is also aware of the unbearable pain and undefinable existential anguish of the modern man, who finds himself in a state of alienation and isolation.

Man as he is, folly

Vice, error, deceit.....(Mirrored Man 16)

Besides being excellent in the thematic expression, it is magnificent in its artistic beauty and perfection in its diction. Selection of words is effortless for him to represent his thoughts. He himself admits that

I came home with some verse in me that would not let me rest

Until I put it down on the plain paper. Then I worked on it till it

Turned out to be a poem. (GM 105).

The poem Love Song of a Journeyman interprets the different aspects of unrequited love of a journeyman. It delineates the unsuccessful love of a journeyman who is betrayed by his lover. Love and Lust can be compared together in terms of a true love. A true love never fades, but in the poem Love Song of a Journeyman the lover of the journeyman 
seems more lustful than to love his beloved. If the love is true then there is no way of betrayal, but if it is only lust, then no love will exist between two lovers. Lust is important in order to love someone, but to love for a lust can never be a true love. In this poem, the lover chooses the life of the city than to be with the journeyman and his dreams are shattered and broken. The betrayed and ignored journeyman laments the agony of a long journey of his broken love life whose lover did never turn back to him and for the rest of his life he is living in the memory of his beloved. The sadness of the man is that he is being lonely and his heart is empty.

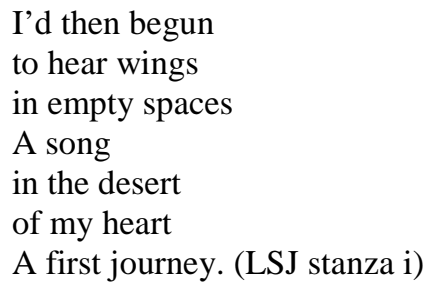

The poem is the reflection of the poet's own innermost feelings and experience of his life. Most of the poems are based on his experience. This poem describes the different aspects of love and its importance. It shows the way Lust becomes an important component of love and thus, Love here becomes a broken desire of the journeyman. For every loverlove comes first and lust later, but in this poem the beloved of the man did not love her truly and she betrayed him, leaving him all alone and she has "revealed the edge of a dream" of her lover.

In an interview he describes his process of writing poetry, about how he observes certain things and events, and those things and events remain in his mind and he reflects over them, jots them down after a thorough and deep study of the particular phenomenon, and poetry for him is a craft which involves a very labour on the part of the creator rather than being a spontaneous overflow of powerful feelings. He embarks on the sunny sides of several topics under his inspection, churns over it again shows his favour or distaste, and infers it with the bevy of crisp comment or a punch on the maladies of man-made malignity. The glory of the city has withered. This loss he commemorates with a glance rapture in his heart.In The Bunyan Tree he personifies the city and defines it as

This aged city facing the withered glory, now wrinkled, cracked, weather - beaten with dim eyes

In this poem he expresses the social ingratitude with a pang banging against the callous side of sophisticated society.

In the poem Prayer he wants to rescue at once from the absurdity of the city life:

this

absurd city

City within

a city

cities leading

you nowhere

rescue us

Lord

at once

show us

some 


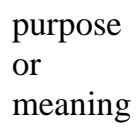

The poet says that with the change of era and due to the blind race of industrialization and advancement in technology, many trees like Banyan Trees have been cut down and the clean water of the river has been polluted by people due to the inhabitation and the natural resources are either distracted or polluted. The poem "Summer Hill Devdar" deals with the natural beauty of the devdar trees deals with the event of Shimla, $19^{\text {th }}$ June, 2001. The tall and silent trees don't announce the horrific news of the tragedy and the anguish of the victims. Their corpses were buried in the white fog and the devdar trees stand as a witness of their deaths. Vihang A. Naik's next poem "Gujarat" also deals with the earthquake tragedy on $26^{\text {th }}$ January, 2001 that killed many people in Gujarat. The intensity of the earthquake was 7.9 onthe Richter scale. There were countless deaths on that day.

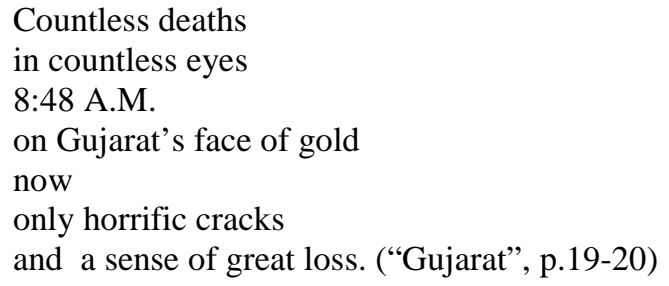

Inshort, his poems provide the reader a mirror to look into life and it is common to find some expression of glory and misery that people feel in their life. After going through Vihang A. Naik's poetry, it can be concluded that Vihang Ashokkumar Naik hits upon burning issues of all times and it makes his poetry unparalleled, unique and exquisite and thus, he excels many other contemporary poets. Professor Vihang is an a very renowned poet from Gujarat and if he can be elevated to the level of John Keats, William Wordsworth, Nissim Ezekiel, Robert Frost, A.K. Ramanujan, ArunKolatkar there will be no exaggeration in this statement. His poetry deals with so many significant themes and embarkation of such themes can be done with only intellectually-gifted and versatile poets and Vihang A. Naik, in fact, is not an exception. He deals with those themes which deserve mention in his poetry. His poetry is enriched with the intellectual maturity, philosophical view, aesthetical exquisiteness, critical insights, inspirational words and motivational zeal despite the galls of life which torment us and his poetry provides a cooling respite from the traumatic and torrid experiences of life which are indistinguishable part of life. His unique craft of writing, intellectual aptitude, touching themes and impressive language had made him an international figure.

\section{STYLE AND DICTION}

Vihang A Naik, a bilingual writer, uses English with affluence to suit his themes pinched from the various walks of life. His writing style is free from the shackles and the different themes takenby him for his poems, distinguished him from other poets of Indian writing in English. His poems are short, crisp and concise, but honeyed with deep meaning. His short lines attract with image and phrases that speak themselves to the reader. His lines in New Websight runs like this And life...Search....Site not found, simple in style, then again, it depicts the search of the aimless life of the modern man, who in turn forgets to live a life of balance. These three words speak volumes. This unique style of using simple words to illustrate volumes of modern man, places him renowned among the Indian writers. His peculiar style of composition, terse as it is always there, imparts a message of being and becoming a wise man in a humane way in perhaps inhuman world around us.He is natural and dexterous in the selection of words to suit his themes and made him exceptional among other 
writers. His selection of words accurately mirrors men and manners of modern era.

\section{Comment}

Vihang A Naik's works are credible for more research. The future scholars can study the authentic selection of diction and exhaustive significance of the poems as they clearly mirror the modern world.

\section{REFERENCES}

1. Arolia, Jitendra. "Kaleidoscopic Vision in the VihangNaik's Poetry: Manifesto." Research Scholar: An International Refereed e-Journal of Literary Explorations I. II (2013): 1-4. Print.

2. Arora, Sudhir K. "Reflective and Aesthetic Landscapes: The Poetry of Vihang A. Naik." Indian Writing in English: Critical Insights. Ed. Singh, Bijender. New Delhi: Authorspress, 2014. 77-88. Print.

3. Bhaskar, JhaBhaskaranand. "Vihan A Naik's City Times and Other Poems." Boloji.com. Web. Accessed on 14/04/2016 "Vihang A Naik's Poetry Manifesto: Manifestation of Manifold Musings." Web. Accessed on 15/04/2016 Biswas, Gargi.

4. "A Dawn of Destruction Reflected in the Poetry of Vihang A. Naik." International Journal of English Research. 2.1. (2016): 04-07. . Psychoanalytic Study of Vihang A. Naik's Poetry Manifesto (New and Selected Poems). Research Front. 3.4. (2015): 21-26.

5. Dixit, Kalyani. "Colossal Range of Experiences and Philosophical Vision of Vihang A. Naik in Poetry Manifesto (New and Selected Poems).” Research Scholar: An International Refereed eJournal of Literary Explorations I. IV (2013): 248-252.

6. Naik, Vihang A. Interview with NabanitaDhar. Isahitya. 2011. Print.

7. Patva, Durga. "Poetry of Vihang A. Naik: A Study of Poetic Creation and Theme of Multi-Aspects of Contemporary Life." International Journal of Social Science and Humanities Research. IV.I. (2016): 451-458.

8. Sarangi, Jaydeep. “JaydeepSarangi in Conversation with VihangNaik.” Ed. Jha, Vivekanand. VerbalArt: A Global Journal Devoted to Poets and Poetry. 1.2. (2015): 98-106.

9. Sheikh, Shamenaz. "Vihang A. Naik's Poetry Manifesto. Boloji.com 7 Dec. 2012. Web. Accessed on 15/04/2016.

10. Naik, Vihang A. "City Times Other Poems. Bloomington USA: Authorhouse, 3 May 2014. English

11. Nishant Sharma, Shashikant. "Social Realism in Poetry and VihangNaik", International Journal of Research, vol.4.6., May 2017. Print. 
